\title{
Próba oceny zróżnicowania nasilenia antropopresji w zlewniach 2. rzędu w Górach Świętokrzyskich
}

\author{
Attempt to assess the differentiation of intensity of anthropopression in the second-order \\ river basins of the Holy Cross Mountains
}

\author{
Katarzyna Koper \\ Instytut Geografii, Uniwersytet Jana Kochanowskiego w Kielcach, Kielce, katarzynakoper88@gmail.com
}

Zarys treści: W pracy dokonano próby oceny zróżnicowania nasilenia antropopresji w zlewniach 2. rzędu w Górach Świętokrzyskich. Wykorzystując wskaźnik antropopresji, uwzględniający: udział poszczególnych form użytkowania terenu, stopień zdrenowania obszarów oraz gęstość zaludnienia, dokonano oceny porównawczej nasilenia antropopresji. Terenem najbardziej nasilonej antropopresji w Górach Świętokrzyskich jest typowo rolnicza i w znacznym stopniu wylesiona zlewnia Koprzywianki. W pracy przeanalizowano również zróżnicowanie wartości wskaźnika antropopresji w zlewniach 2. rzędu Gór Świętokrzyskich w zależności od ukształtowania terenu oraz odległości od miast. Obszary położone na znacznych wysokościach bezwzględnych i terenach o dużych spadkach charakteryzują się mniejszymi rozmiarami antropopresji, natomiast nasilenie antropopresji wzrasta w miastach $\mathrm{i}$ na terenach do nich przyległych. W pracy dokonano również porównania wartości wskaźnika antropopresji na podstawie dwóch typów danych: statystycznych oraz przestrzennych, a następnie wskazano możliwości i ograniczenia wykorzystania każdego z analizowanych typów danych.

Słowa kluczowe: wskaźnik antropopresji, ocena antropopresji, Góry Świętokrzyskie

\begin{abstract}
The paper attempts to assess the differentiation of intensity of anthropogenic impact in the secondary river basins of the Holy Cross Mountains. Using the anthropogenic impact indicator, taking into account the contribution of individual forms of land use, the level of drainage of areas and population density, a comparative assessment of the intensity of anthropogenic impact was conducted. The area of most severe anthropogenic impact in the Holy Cross Mountains is a typically agricultural and largely deforested basin of Koprzywianka River. The paper also examines the diversity of the value of anthropogenic impact index in the secondary river basins of the Holy Cross Mountains, depending on terrain and distance from cities. Areas of substantial altitudes and areas with large declines are characterized with lower level of anthropogenic impact, while the intensity of anthropogenic impact increases in urban areas and areas adjacent thereto. The paper also compared the results of calculation of the anthropogenic impact indicator on the basis of two types of data: statistics and spatial, and the opportunities and limitations of using each of the data types were indicated.
\end{abstract}

Key words: anthropopression index, assessment of anthropopression, Holy Cross Mountains

\section{Wstęp}

Obieg wody w zlewni kształtowany jest przez czynniki naturalne i antropogeniczne. Te drugie mogą mieć charakter bezpośredniej ingerencji w stosunki wodne bądź oddziaływania pośredniego poprzez przekształcenia środowiska geograficznego zlewni (por. Wilgat 1978, Dynowska 1993). Wpływ człowieka na obieg wody jest przedmiotem wielu opracowań, głównie dotyczących obszarów miejskich i przemysłowych (m.in. Soczyńska
1974, Jankowski 1986, 1998, Maruszczak 1986, Czaja 1988, 1999, 2002, Michalczyk, Łoś 1996, Absalon 1998, Nowicka 2002, Ciupa 2009, Michalczyk 2012). Dotychczas nie wypracowano jednak uniwersalnej metody oceny ilościowej wpływu człowieka na obieg wody w zlewni (Kostrowicki 1992, Plit 1996, Piotrowska 2001, Soja 2002, Ciupa 2010, Giełda-Pinas 2012). Podstawowym problemem oceny antropopresji jest dostępność danych jedynie dla jednostek podziału administracyjnego, które nie pokrywają się z granicami zlewni rzecznych. Jednak- 
że nowe możliwości oceny antropopresji, niezależnie od granic administracyjnych, stwarza wykorzystanie narzędzi GIS i danych przestrzennych.

Celem pracy jest próba oceny nasilenia antropopresji w zlewniach 2. rzędu w Górach Świętokrzyskich z wykorzystaniem wskaźnika antropopresji. W pierwszej części pracy dokonano analizy porównawczej wartości wskaźnika antropopresji w poszczególnych zlewniach mezoregionu. W drugiej części przeanalizowano zróżnicowanie wartości wskaźnika antropopresji w poszczególnych zlewniach 2. rzędu Gór Świętokrzyskich, uwzględniając ukształtowanie $\mathrm{z}$ terenu oraz odległość od ośrodków miejskich. Praca prócz znaczenia poznawczego porusza również problematykę metodologiczną, tj. ocenę wykorzystania danych statystycznych lub przestrzennych do obliczania wartości omawianego wskaźnika. Problematyka ta omówiona została w trzeciej części artykułu. Ponadto wskazano tu możliwości i ograniczenia wykorzystania każdego z tych typów danych.

\section{Obszar badań}

Teren badań położony jest w granicach Gór Świętokrzyskich, obejmując fragmenty zlewni czterech rzek 2. rzędu odwadniających tenże mezoregion, tj. zlewnie: Nidy, Kamiennej, Czarnej i Koprzywianki (ryc. 1). W pracy nie uwzględniono natomiast zlewni Opatówki z uwagi na niewielki odsetek jej powierzchni (6\%), występujący $\mathrm{w}$ granicach mezoregionu oraz nieznaczny udział w odwadnianiu Gór Świętokrzyskich (0,9\%).

W strukturze użytkowania ziemi badanych zlewni dominują grunty orne oraz lasy (tab. 1) i są to wraz z pozostałymi gruntami te kategorie użytków, których udział w poszczególnych zlewniach mezoregionu charakteryzuje się największym zróżnicowaniem. Na tle Gór Świętokrzyskich największym udziałem gruntów ornych w strukturze użytkowania ziemi cechuje się zlewnia Koprzywianki (77\%), natomiast najmniejszym - zlewnia Nidy (43,7\%). Pod względem lesistości wyróżnia się zlewnia Koprzywianki (16,8\%), będąca obszarem o najniższym udziale lasów w strukturze użytkowania ziemi. W przypadku pozostałych gruntów (głównie obszarów przemysłowych i zurbanizowanych) wyróżnia się zlewnia Nidy, z największym udziałem tej kategorii użytków

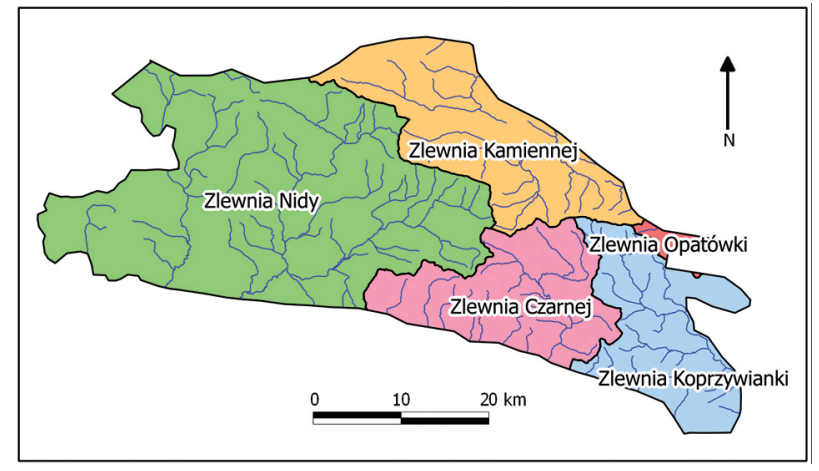

Ryc. 1. Zlewnie 2. rzędu w Górach Świętokrzyskich

Fig. 1. Second-order river basins in Holy Cross Mountains

(10,8\%). Udział terenów zdrenowanych jest zróżnicowany i zawiera się w przedziale od 4,73 do 14,16\%.

W obrębie poszczególnych zlewni 2. rzędu Gór Świętokrzyskich znacznie zróżnicowana jest gęstość zaludnienia, od 68,5 os. $\mathrm{km}^{-2} \mathrm{w}$ zlewni Czarnej do 208 os. $\mathrm{km}^{-2} \mathrm{w}$ zlewni Nidy. W granicach mezoregionu położone jest miasto wojewódzkie Kielce (200 938 osób - stan na 31.12.2012 r.) oraz trzy małe ośrodki miejskie: Daleszyce, Chęciny i Bodzentyn. Na pozostałych obszarach zabudowa jest rozproszona.

\section{Metody badań}

W opracowaniu wykorzystano metodę obliczania wskaźnika antropopresji, którą Soja (2002) stosował w Karpatach. Autor ten skonstruował następujący wzór do obliczania wskaźnika antropopresji:

$$
P=\frac{G O+P G+O Z}{P Z+U Z+S}+K
$$

gdzie: GO - powierzchnia gruntów ornych $\left(\mathrm{km}^{2}\right), \mathrm{PG}$ - pozostałe grunty $\left(\mathrm{km}^{2}\right), \mathrm{OZ}$ - obszary zmeliorowane $\left(\mathrm{km}^{2}\right), \mathrm{PZ}$ - powierzchnie zalesione $\left(\mathrm{km}^{2}\right), \mathrm{UZ}$ - użytki zielone $\left(\mathrm{km}^{2}\right), \mathrm{S}$ - sady $\left(\mathrm{km}^{2}\right), \mathrm{K}$ - współczynnik gęstości zaludnienia.

Takie składowe, jak grunty orne, pozostałe grunty oraz obszary zmeliorowane, zalicza się do terenów, gdzie obieg wody znajduje się pod wpływem antropopresji, zaś powierzchnie zalesione, użytki zielone oraz sady - to ob-

Tabela 1. Struktura użytkowania terenu w zlewniach 2. rzędu w Górach Świętokrzyskich (dane wg CORINE Land Cover 2006)

Table 1. Structure of land use in the second-order river basins in Holy Cross Mountains (according to CORINE Land Cover 2006)

\begin{tabular}{|c|c|c|c|c|c|}
\hline & Wyszczególnienie & Zlewnia Czarnej & Zlewnia Kamiennej & Zlewnia Koprzywianki & Zlewnia Nidy \\
\hline \multirow{6}{*}{ 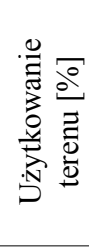 } & Grunty orne & 55,85 & 58,56 & 77,10 & 43,67 \\
\hline & Lasy & 37,23 & 31,92 & 16,80 & 37,08 \\
\hline & Łąki i pastwiska & 4,83 & 5,76 & 3,40 & 8,18 \\
\hline & Pozostałe grunty & 1,75 & 3,76 & 2,70 & 10,82 \\
\hline & Sady & - & - & - & 0,03 \\
\hline & Zbiorniki wodne i bagna & 0,33 & - & - & 0,23 \\
\hline \multicolumn{2}{|c|}{ Obszary zdrenowane } & 7,83 & 10,93 & 14,16 & 4,73 \\
\hline \multicolumn{2}{|c|}{ Gęstość zaludnienia [os.km²] } & 68,48 & 88,71 & 75,66 & 207,97 \\
\hline
\end{tabular}


szary o obiegu wody zbliżonym do naturalnego. Współczynnik K uwzględnia gęstość zaludnienia, a jego wartość dla poszczególnych zlewni ustalono w oparciu o średnią gęstość zaludnienia dla Gór Świętokrzyskich (ok. 153 os. $\mathrm{km}^{-2}$ ). Wzorując się na metodzie wykorzystanej przez Soję (2002), wartość powyższego współczynnika określono w przedziale od $-0,4$ do $+0,4$, stosując następujące kryteria:

- $30-60$ os. $\mathrm{km}^{-2}-\mathrm{K}=-0,4$,

- 60-90 os. $\mathrm{km}^{-2}-\mathrm{K}=-0,3$,

- $90-120$ os. $\mathrm{km}^{-2}-\mathrm{K}=-0,2$,

- $120-153$ os. $\mathrm{km}^{-2}-\mathrm{K}=-0,1$,

- $153-180$ os. $\mathrm{km}^{-2}-\mathrm{K}=+0,1$,

- powyżej 180 os. $\mathrm{km}^{-2}-\mathrm{K}=+0,4$.

Obszarom o gęstości zaludnienia niższej niż wartość średnia dla Gór Świętokrzyskich, ze względu na mniejszą presję na obieg wody, przypisano ujemną wartość współczynnika $\mathrm{K}$, natomiast obszarom o gęstości zaludnienia wyższej od średniej - wartość dodatnią. Dla Kielc, jedynej gminy Gór Świętokrzyskich o gęstości zaludnienia wyższej niż 180 os. $\mathrm{km}^{-2}$, w celu podkreślenia odrębności na tle innych gmin mezoregionu ustalono skokowo wartość współczynnika na $+0,4$.

W pierwszej części pracy przeanalizowano zróżnicowanie wartości wskaźnika antropopresji w Górach Świętokrzyskich. Na podstawie danych przestrzennych analizowanych $\mathrm{z}$ wykorzystaniem oprogramowania Quantum GIS obliczono wartości wskaźnika antropopresji w obrębie granic zlewni Gór Świętokrzyskich. Powierzchnię poszczególnych użytków obliczono na podstawie wektorowej mapy pokrycia terenu wykonanej w ramach programu CORINE Land Cover 2006 (EEA 2013) przez Europejską Agencję Środowiska (www.eea. europa.eu). Powyższa mapa uwzględnia pokrycie terenu dla obszarów o powierzchni co najmniej 25 ha i minimalnej szerokości $100 \mathrm{~m}$. Po dokonaniu transformacji układu współrzędnych z ETRS89/ETRS-LAEA do PUWG92, który przyjęto jako podstawowy dla niniejszego opracowania, stwierdzono występowanie w granicach Gór Świętokrzyskich 19 klas pokrycia terenu (GIOŚ 2008). Na potrzeby niniejszego opracowania dokonano generalizacji wydzieleń mapy do postaci 7 klas pokrycia terenu (ryc. 2), a następnie do obliczania wartości wskaźnika antro-

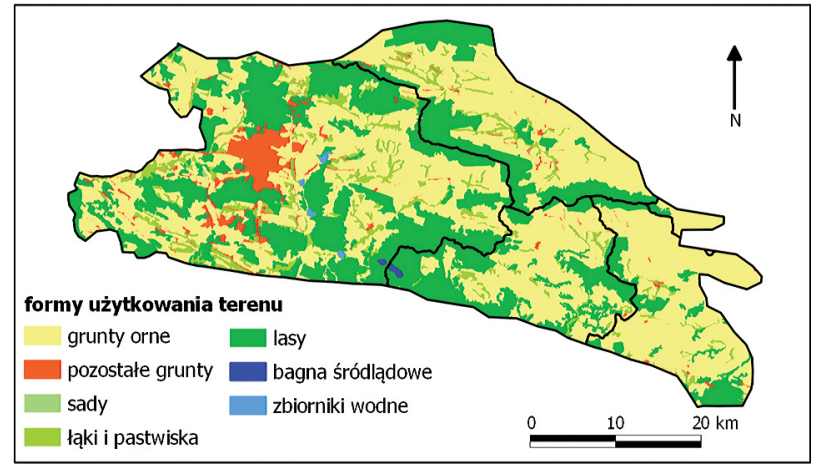

Ryc. 2. Użytkowanie terenu w zlewniach 2. rzędu w Górach Świętokrzyskich (CORINE Land Cover 2006)

Fig. 2. Use of land in the second-order river basins in Holy Cross Mountains (CORINE Land Cover 2006)

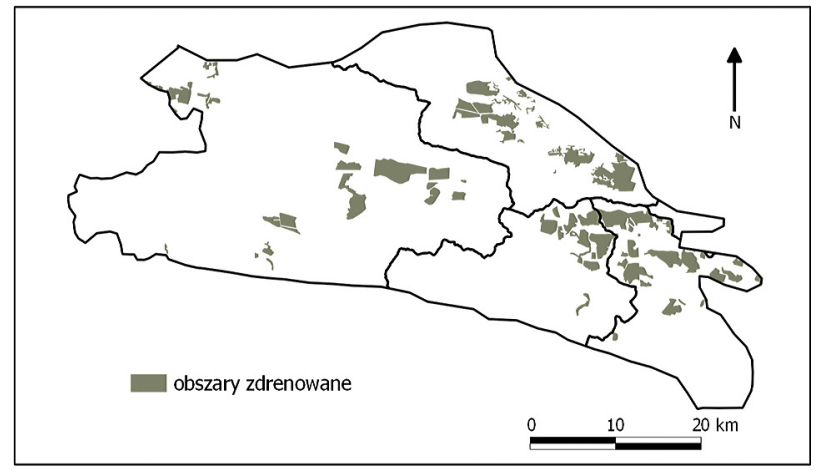

Ryc. 3. Obszary zdrenowane w Górach Świętokrzyskich (Mapa Hydrograficzna Polski)

Fig. 3. Drained areas in Holy Cross Mountains (Hydrological Map of Poland)

popresji wykorzystano 5 klas użytkowania terenu (grunty orne, pozostałe grunty, lasy, łąki i pastwiska, sady). Warstwę wektorową obszarów zdrenowanych dla poszczególnych zlewni pozyskano z 14 arkuszy numerycznej Mapy Hydrograficznej Polski w skali 1:50 000 (układ współrzędnych PUWG92) (ryc. 3). Na podstawie wymienionych wyżej danych przestrzennych, z wykorzystaniem oprogramowania Quantum GIS, obliczono powierzchnie każdej z klas użytków oraz powierzchnie terenów zdrenowanych w granicach poszczególnych zlewni. Powyższe dane wraz z wartościami współczynnika gęstości za-
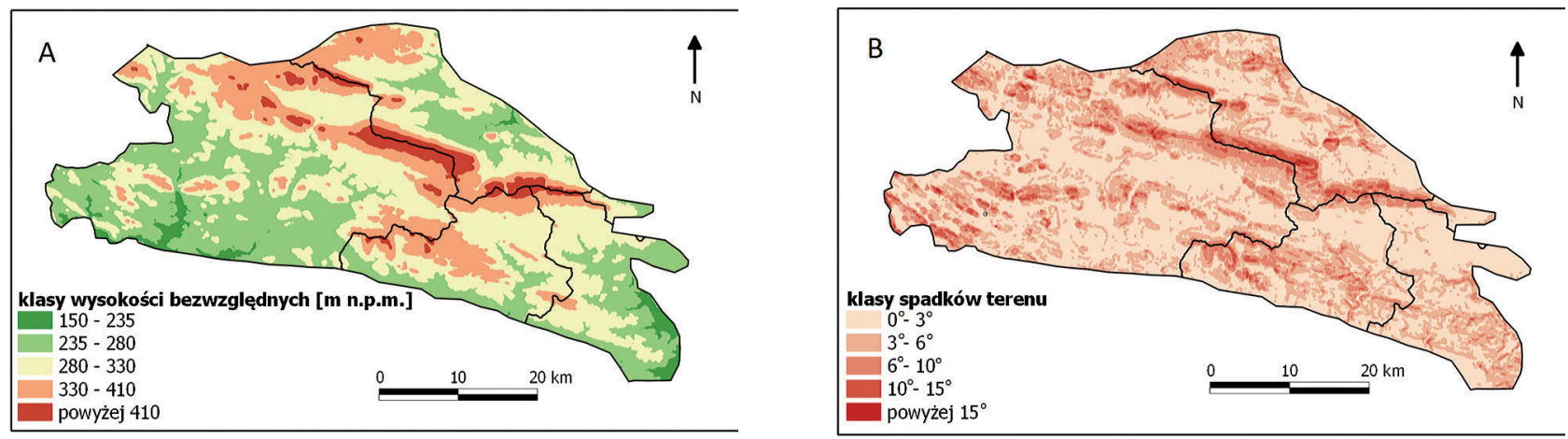

Ryc. 4. Klasy wysokości bezwzględnych (A) i spadków terenu (B) w zlewniach Gór Świętokrzyskich

Fig. 4. Intervals of altitude (A) and terrain slope (B) in Holy Cross Mountains 


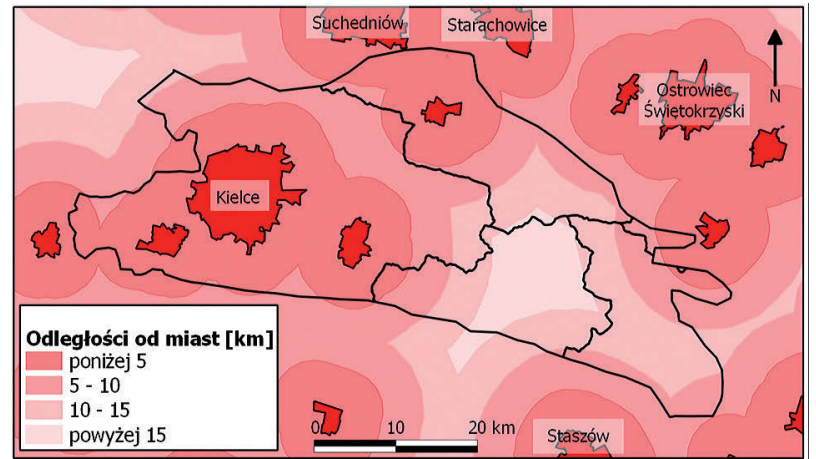

Ryc. 5. Klasy odległości od miast w zlewniach Gór Świętokrzyskich

Fig. 5. Intervals of distance from the city in river basins in Holy Cross Mountains

ludnienia (K) umożliwiły obliczenie wartości wskaźnika antropopresji bezpośrednio dla każdej ze zlewni 2. rzędu Gór Świętokrzyskich.

W drugiej części pracy, wykorzystując dane przestrzenne analizowane za pomocą oprogramowania Quantum GIS, określono zróżnicowanie wartości wskaźnika antropopresji w zlewniach 2. rzędu Gór Świętokrzyskich w zależności od ukształtowania terenu i odległości od miast.

Do analizy nasilenia antropopresji $\mathrm{w}$ zależności od ukształtowania terenu wykorzystano cyfrowy model wysokościowy SRTM v.4 o rozdzielczości 3 sekund, tj. około $90 \mathrm{~m}$ (CGIAR-CSI 2004). Po dokonaniu transformacji układu współrzędnych (z WGS84 do PUWG92) na podstawie cyfrowego modelu wysokościowego opracowano w granicach Gór Świętokrzyskich mapę ukształtowania terenu oraz mapę spadków, a następnie dokonano ich reklasyfikacji. Wygenerowano z pierwszej z nich klasy wysokości bezwzględnych (150-235, 235-280, 280-330, 330-410, powyżej 410 m n.p.m.) (ryc. 4A), a z drugiej klasy spadków terenu $(0-3,3-6,6-10,10-15$, powyżej $15^{\circ}$ ) (ryc. 4B). Przedziały wysokości bezwzględnych i spadków terenu dobrano w sposób adekwatny do rozkładu ich wartości w Górach Świętokrzyskich. Stosując operację mnożenia warstw, obliczono powierzchnie form użytkowania terenu oraz powierzchnie obszarów zdrenowanych w obrębie każdej z klas wysokości bezwzględnych i klas spadków terenu. Dla każdej z klas, w obrębie poszczególnych zlewni, przyjęto średnią gęstość zaludnienia dla danej zlewni i na tej podstawie ustalono wartość współczynnika gęstości zaludnienia (K).

W dalszej części pracy przeanalizowano zróżnicowanie wartości wskaźnika antropopresji w poszczególnych zlewniach w zależności od odległości od ośrodków miejskich. Na podstawie map topograficznych $\mathrm{z}$ wykorzystaniem oprogramowania Quantum GIS wykonano wektorową warstwę granic miast, którą poddano operacji buforowania, ustalając następujące przedziały odległości od miast: $0-5 \mathrm{~km}, 5-10 \mathrm{~km}, 10-15 \mathrm{~km}$ oraz powyżej 15 $\mathrm{km}$ (ryc. 5). Obliczono powierzchnię użytków oraz obszarów zdrenowanych $\mathrm{w}$ granicach miast, a także w po-

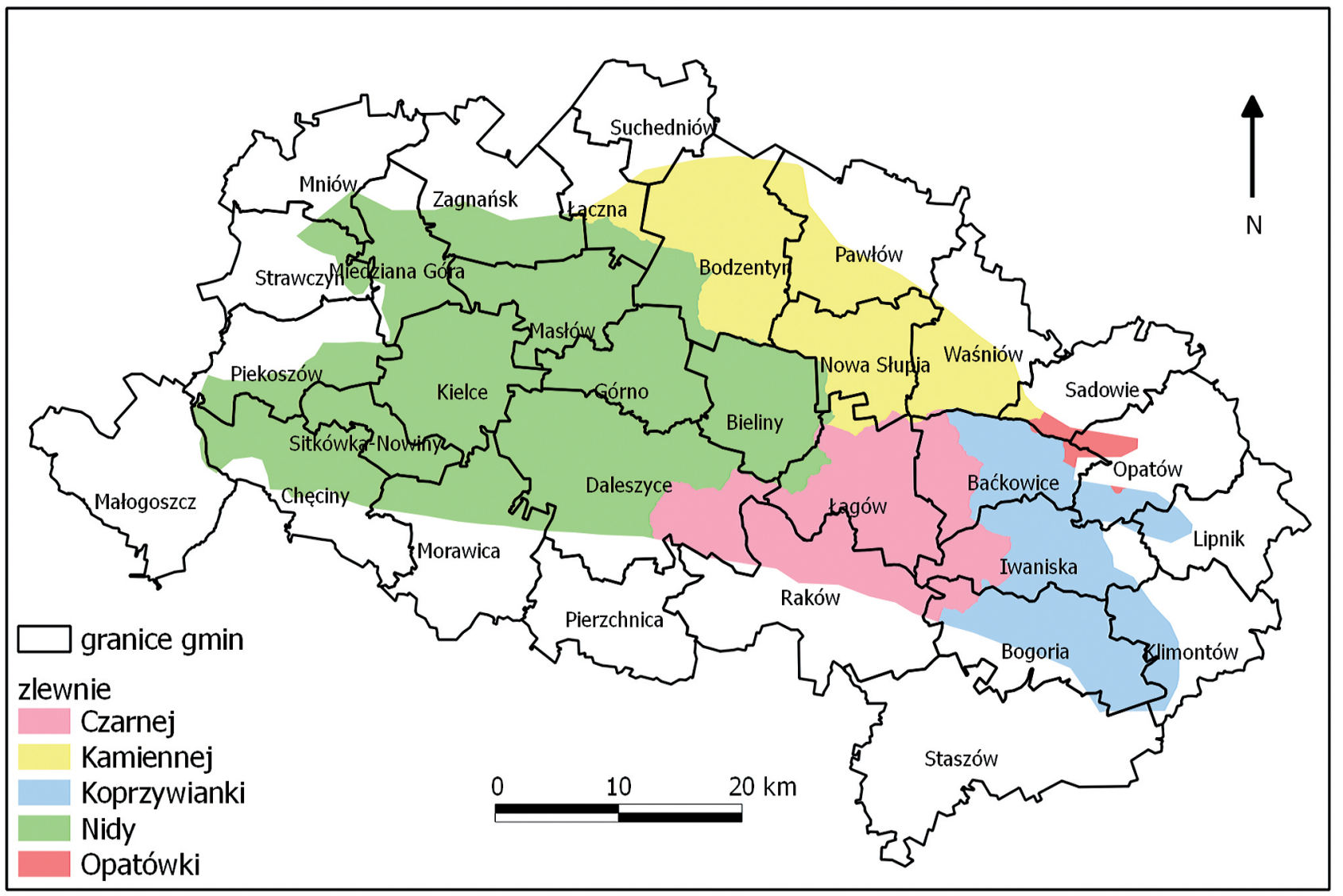

Ryc. 6. Gminy Gór Świętokrzyskich na tle zlewni 2. rzędu

Fig. 6. The communities of Holy Cross Mountains against the background of the second-order river basins 
szczególnych klasach odległości od nich. Współczynnik $\mathrm{K}$ dla obszarów miast określono na podstawie gęstości zaludnienia w ich obrębie, natomiast dla poszczególnych klas odległości od tych ośrodków przyjęto wartość K jako średnią dla zlewni. Omówione postępowanie pozwoliło na określenie wartości wskaźnika antropopresji w obrębie miast i klas odległości od nich w analizowanych zlewniach Gór Świętokrzyskich.

W trzeciej części pracy porównano wartości wskaźnika antropopresji uzyskane dla poszczególnych zlewni 2. rzędu na podstawie danych przestrzennych z obliczeniami przeprowadzonymi na podstawie danych statystycznych, tak jak to zaproponował Soja (2002).

Dla każdej z badanych zlewni obliczono wartości wskaźnika antropopresji na podstawie danych statystycznych dla 31 gmin, leżących w całości (7 gmin) lub częściowo (24 gminy) w Górach Świętokrzyskich (ryc. 6). Dla poszczególnych gmin z GUS pozyskano informacje o gęstości zaludnienia, powierzchni poszczególnych użytków (gruntów ornych, pozostałych gruntów i nieużytków, lasów, łąk i pastwisk, sadów), natomiast ze Świętokrzyskiego Zarządu Melioracji i Urządzeń Wodnych w Kielcach - powierzchnię obszarów zmeliorowanych. Na podstawie powyższych danych dla każdej z gmin obliczono wartość wskaźnika antropopresji. Następnie wartości te uogólniono do obszarów zlewni rzecznych, obliczając średnią arytmetyczną z wartości wskaźnika antropopresji dla gmin wchodzących w skład poszczególnych zlewni.

\section{Wyniki badań}

\section{Zróżnicowanie wartości wskaźnika antropopresji w Górach Świętokrzyskich}

W pierwszej części pracy obliczono na podstawie danych przestrzennych wartości wskaźnika antropopresji dla zlewni 2. rzędu w Górach Świętokrzyskich (tab. 2). Obliczone wartości umożliwiają przeprowadzenie analizy zróżnicowania antropopresji w mezoregionie, a więc określenie, która ze zlewni jest potencjalnie w największym stopniu narażona na zmiany obiegu wody spowodowane presją antropogeniczną.

W granicach badanych zlewni stwierdzono zróżnicowanie wartości wskaźnika antropopresji (tab. 2). Najwyższa wartość omówionego wskaźnika występuje w Górach Świętokrzyskich w zlewni Koprzywianki $(4,35)$. W przypadku tejże zlewni wysoka wartość wskaźnika uwarunkowana jest głównie znacznym udziałem powierzchni gruntów ornych (ok. 77\%), przy jednoczesnym niewielkim odsetku lasów (16,8\%) (tab. 1). Zlewnia Koprzywianki, jako obszar o najwyższej wartości wskaźnika antropo- presji, jest na tle Gór Świętokrzyskich w największym stopniu narażona na zmiany obiegu wody wywołane działalnością człowieka. Pozostałe zlewnie 2. rzędu tego mezoregionu charakteryzują się natomiast mniejszym i porównywalnym nasileniem antropopresji. W zlewni Nidy wartość wskaźnika antropopresji kształtowana jest $\mathrm{z}$ jednej strony przez najwyższą $\mathrm{w}$ regionie gęstość zaludnienia $\left(208\right.$ os. $\left.\mathrm{km}^{-2}\right)$ i wysoki udział pozostałych gruntów (10,8\%), w tym terenów objętych zabudową miejską, związanych z miastem Kielce. Z drugiej strony czynnikiem, który obniża wartość wskaźnika antropopresji w tej zlewni, jest duży odsetek lasów (37\%) oraz najniższy spośród analizowanych zlewni udział gruntów ornych (43,7\%). Jedna z niższych wartości wskaźnika antropopresji w regionie występuje w zlewni Kamiennej i wynika ze stosunkowo niewielkiej gęstości zaludnienia $(88,7$ os. $\mathrm{km}^{-2}$ ) w porównaniu do innych zlewni oraz znacznego udziału lasów (31,9\%). Zlewnia Czarnej jest obszarem o najniższej wartości wskaźnika antropopresji, co jest efektem niewielkiej gęstości zaludnienia (68,5 os. $\mathrm{km}^{-2}$ ) oraz najwyższego odsetka lasów $(37,2 \%)$ na tle wszystkich analizowanych zlewni.

\section{Zróżnicowanie wartości wskaźnika antropopresji w zlewniach 2. rzędu w Górach Świętokrzyskich}

W drugiej części opracowania przeanalizowano zróżnicowanie wartości wskaźnika antropopresji w obrębie zlewni 2. rzędu w Górach Świętokrzyskich w zależności od ukształtowania terenu (wysokości bezwzględnych i spadków terenu) oraz odległości od miast.

Spośród wyróżnionych 5 klas wysokości bezwzględnych (150-235, 235-280, 280-330, 330-410, powyżej 410 m n.p.m.) (ryc. 4A) w Górach Świętokrzyskich wyraźnie najniższe wartości wskaźnika antropopresji w przypadku każdej ze zlewni zaobserwowano w przedziale powyżej $410 \mathrm{~m}$ n.p.m. (ryc. 7). Wyjątek stanowi zlewnia Czarnej, gdzie najniższa wartość wskaźnika antropopresji została odnotowana dodatkowo w przedziale 150-235 m n.p.m. Dostrzeżono zatem, że w przypadku zlewni Gór Świętokrzyskich najniższe wartości analizowanego wskaźnika są charakterystyczne na ogół dla terenów o największych wysokościach bezwzględnych. W obrębie niższych wysokości n.p.m. wartości tego wskaźnika zdecydowanie wzrastają, osiągając wartość maksymalną w przedziałach 280-330 m n.p.m. (zlewnie Czarnej i Koprzywianki) i 235-280 m n.p.m. (zlewnia Kamiennej) lub w przedziałach $150-235$ m n.p.m. oraz 235-280 m n.p.m. (zlewnia Nidy). Powyższa zależność jest odzwierciedleniem struktury użytkowania terenu poszczególnych zlewni mezoregionu. Obszary położone na najwyższych wysokościach bezwzględnych w każdej ze

Tabela 2. Wartość wskaźnika antropopresji w zlewniach 2. rzędu w Górach Świętokrzyskich

Table 2. Anthropopression index in the second-order river basins in Holy Cross Mountains

\begin{tabular}{ccccc}
\hline Parametr & Zlewnia Czarnej & Zlewnia Kamiennej & Zlewnia Koprzywianki & Zlewnia Nidy \\
\hline Wartość wskaźnika antropopresji & 1,26 & 1,64 & 4,35 & 1,71 \\
\hline
\end{tabular}




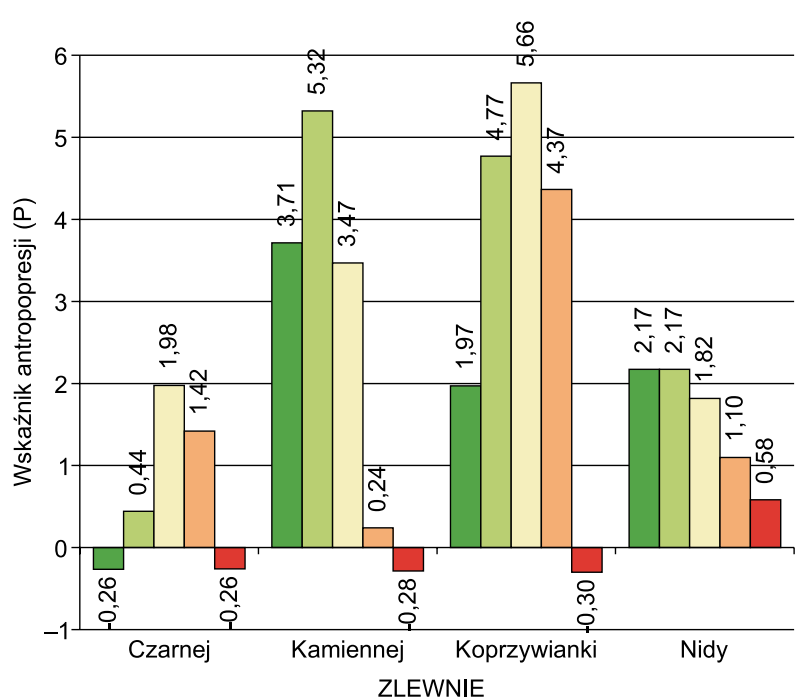

150-235 m n.p.m. $\square$ 280-330 m n.p.m. $\square$ powyżej 410 m n.p.m.

$$
\square \text { 235-280 m n.p.m. } \square \text { 330-410 m n.p.m. }
$$

Ryc. 7. Zróżnicowanie wartości wskaźnika antropopresji w klasach wysokości bezwzględnych zlewniach 2. rzędu w Górach Świętokrzyskich

Fig. 7. Differentiation of the anthropopression index in intervals of altitude in the second-order river basins in Holy Cross Mountains

zlewni obejmują głównie lasy, pozbawione niemal zupełnie rejonów presji antropogenicznej w postaci gruntów ornych czy zabudowy miast. W niższych przedziałach wysokości bezwzględnych w każdej ze zlewni występuje większe zróżnicowanie samych form użytkowania terenu oraz charakteryzują się one większym udziałem gruntów ornych i związanych z nimi obszarów zdrenowanych, a także pozostałych gruntów, w tym szczególnie zabudowy zwartej. Wskutek tego w każdej ze zlewni w niższych przedziałach wysokości bezwzględnych występuje zróżnicowanie wartości wskaźnika antropopresji i nie ma możliwości wskazania ogólnych prawidłowości. Jedynie przykład zlewni Nidy pokazuje wyraźnie, że wraz ze wzrostem wysokości bezwzględnych dochodzi do stopniowego zmniejszenia się wartości wskaźnika antropopresji.

Analizując zróżnicowanie wartości wskaźnika antropopresji w poszczególnych zlewniach względem wyróżnionych 5 klas spadków terenu $(0-3,3-6,6-10,10-15$, powyżej $15^{\circ}$ ) (ryc. 4B), dostrzeżono wyraźne zależności. W przypadku każdej ze zlewni najwyższe wartości wskaźnika antropopresji występują na obszarach o najmniejszych spadkach $\left(0-3^{\circ}\right)$ (ryc. 8). Wraz ze wzrostem nachylenia terenu wartości wskaźnika antropopresji we wszystkich zlewniach wyraźnie maleją, osiągając minimum przy największych spadkach $\left(10-15^{\circ}\right.$ lub powyżej $15^{\circ}$ ). Zróżnicowanie wartości wskaźnika antropopresji w zależności od spadków terenu wykazuje powiązania z użytkowaniem ziemi. Obszary o nieznacznych nachyleniach są predysponowane do rozwoju różnorodnych form użytkowania, w tym upraw rolnych czy zabudowy. W przeciwieństwie do nich tereny o większych spadkach wynoszących od $10^{\circ}$ do ponad $15^{\circ}$ są terenami, gdzie

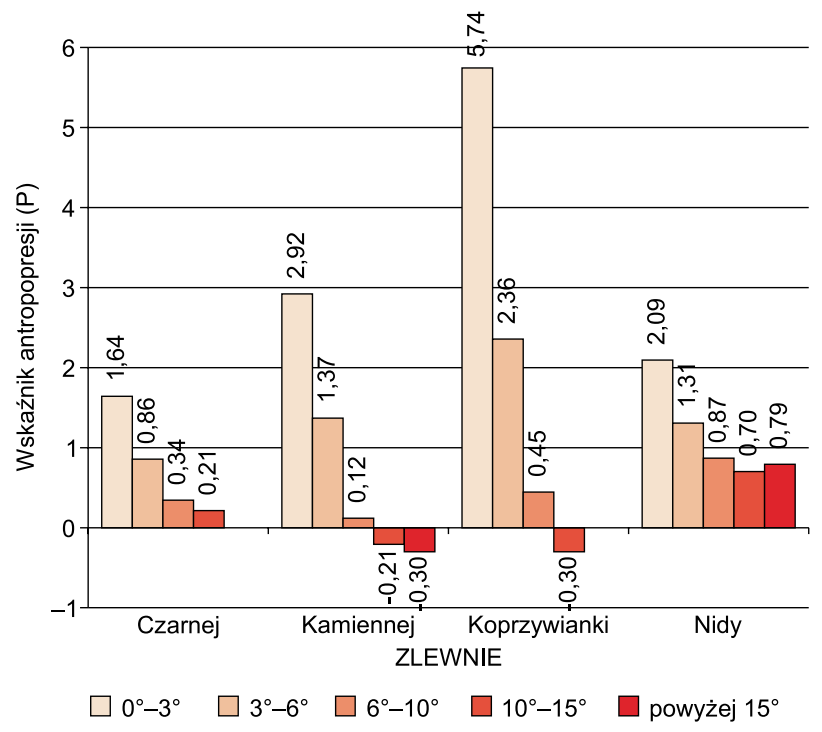

Ryc. 8. Zróżnicowanie wartości wskaźnika antropopresji w klasach spadków terenu w zlewniach 2. rzędu w Górach Świętokrzyskich

Fig. 8. Differentiation of the anthropopression index in intervals of terrain slope in the second-order river basins in Holy Cross Mountains

warunki gospodarowania są bardziej uciążliwe, stąd są to obszary w znacznym stopniu zalesione, z sięgającym jedynie kilkunastu procent udziałem gruntów ornych i pozostałych gruntów.

W analizie zróżnicowania wartości wskaźnika antropopresji w zlewniach Gór Świętokrzyskich względem odległości od ośrodków miejskich zaobserwowano dysproporcję pomiędzy wartościami wskaźnika antropopresji dla terenów w granicach miast a wartościami dla ob-

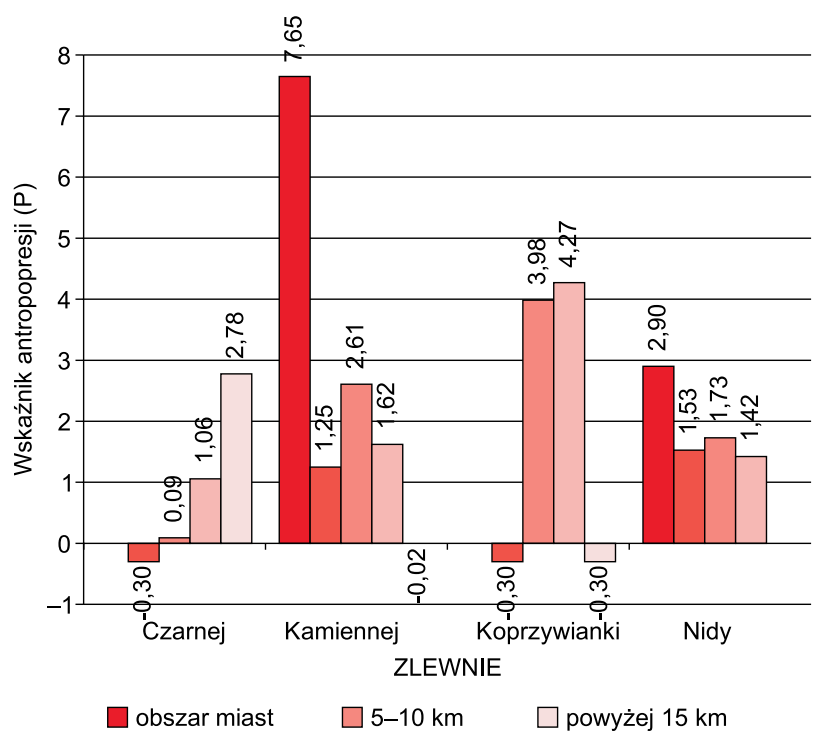

$\square$ poniżej $5 \mathrm{~km} \quad \square 10-15 \mathrm{~km}$

Ryc. 9. Zróżnicowanie wartości wskaźnika antropopresji w klasach odległości od miast w zlewniach 2. rzędu w Górach Świętokrzyskich

Fig. 9. Differentiation of the anthropopression index in intervals of distance from the city in the second-order river basins in Holy Cross Mountains 
szarów leżących poza nimi (ryc. 9). Wartości wskaźnika antropopresji obliczone dla obszarów miejskich wyraźnie przewyższają te charakterystyczne dla terenów przyległych do nich, co wynika $z$ dominującego udziału pozostałych gruntów, w tym zwłaszcza obszarów zabudowy w ogólnej powierzchni miast. Analizując wartości wskaźnika antropopresji w poszczególnych strefach odległości od miast dla zlewni 2. rzędu Gór Świętokrzyskich, dostrzeżono duże zróżnicowanie. Obszary w bezpośrednim sąsiedztwie miast (w odległości do $5 \mathrm{~km}$ ) w każdej ze zlewni charakteryzują się niższą wartością wskaźnika antropopresji w stosunku do obszarów w dalszych przedziałach odległości. W obrębie pozostałych stref odległości od miast zróżnicowanie wartości wskaźnika w przypadku analizowanych zlewni ma charakter przypadkowy, wynikający z rozmieszczenia form użytkowania terenu, które nie wykazuje ścisłego powiązania z odległością od miast.

\section{Zróżnicowanie wartości wskaźnika antropopresji w Górach Świętokrzyskich w zależności od typu danych wykorzystanych do obliczeń}

Porównano wartości wskaźnika antropopresji dla zlewni 2. rzędu w Górach Świętokrzyskich w zależności od typu danych (statystyczne lub przestrzenne) wykorzystanych do obliczeń. Najwyższą wartością wskaźnika antropopresji wyróżnia się na tle mezoregionu zlewnia Koprzywianki (3,53 w przypadku pierwszego sposobu obliczeń oraz 4,35 w przypadku drugiego sposobu) (ryc. 10). W odniesieniu do pozostałych zlewni wartość wskaźnika antropopresji jest zdecydowanie niższa (poniżej 2) (ryc. 10). Jednakże duże zróżnicowanie jego wartości dla poszczególnych zlewni w zależności od sposobu obliczeń powoduje, że nie można wskazać jednoznacznie wśród nich zlewni o najniższej lub najwyższej wartości wskaźnika.

Najbardziej porównywalne wartości wskaźnika antropopresji obliczone na podstawie obu typów danych uzy-

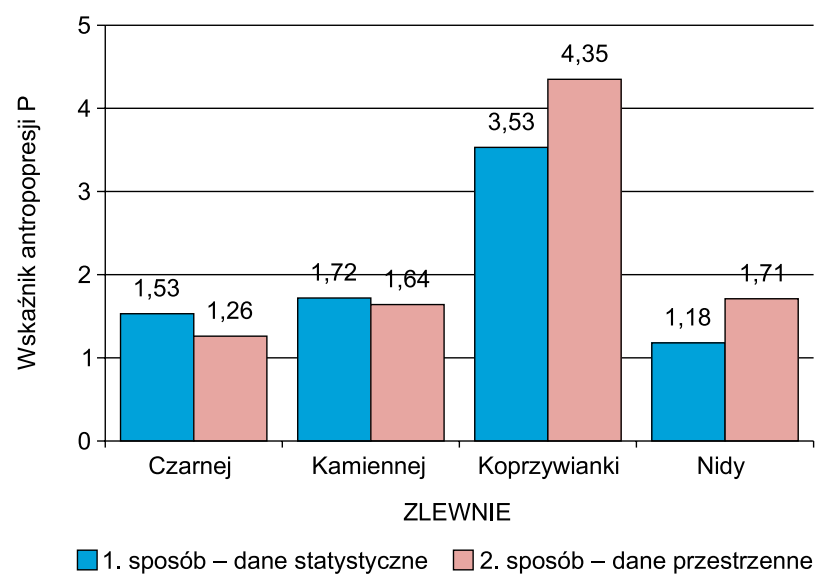

Ryc. 10. Porównanie wartości wskaźnika antropopresji w zlewniach 2. rzędu Gór Świętokrzyskich obliczonych na podstawie danych statystycznych i przestrzennych

Fig. 10. A comparison of the anthropopression index in the second-order river basins in Holy Cross Mountains defined on the basis of statistical and numerical data skano dla zlewni Kamiennej, natomiast największa rozbieżność wartości wskaźnika występuje w przypadku zlewni Nidy. W zlewni Nidy i Koprzywianki wartości wskaźnika dla sposobu opartego na danych przestrzennych są wyższe odpowiednio o 44,9\% i 23,2\% od uzyskanych dla sposobu wykorzystującego dane statystyczne. W zlewniach Kamiennej oraz Czarnej sytuacja jest odwrotna - wartości wskaźnika antropopresji uzyskane drugim sposobem obliczeń są niższe od wartości dla pierwszego sposobu (dla zlewni Kamiennej o 4,9\%, dla zlewni Czarnej o 21,4\%).

Różnice wartości wskaźnika antropopresji uzyskane dwoma sposobami obliczeń wynikają z odmiennych źródeł danych dotyczących użytkowania terenu i powierzchni obszarów zmeliorowanych oraz ich dokładności. Współczynnik gęstości zaludnienia $(\mathrm{K})$ dla obu sposobów obliczeń został ustalony $\mathrm{w}$ analogiczny sposób, a więc na podstawie danych statystycznych dla gmin w Górach Świętokrzyskich.

W przypadku obliczeń dokonywanych na podstawie danych statystycznych odnoszących się do gmin położonych nawet częściowo w granicach Gór Świętokrzyskich dochodzi do znacznego rozszerzenia obszaru analizy poza granice tego mezoregionu. Obszar 31 gmin wchodzących w skład Gór Świętokrzyskich jest niemal dwukrotnie (91\%) większy niż sam obszar w granicach mezoregionu. Wadą sposobu obliczeń bazującego na danych statystycznych jest również potrzeba uogólniania danych dostępnych dla gmin do obszarów systemów przyrodniczych, w tym opracowaniu - zlewni rzecznych. Powyższy sposób obliczeń z powodzeniem może być stosowany do porównywania nasilenia antropopresji w granicach jednostek podziału administracyjnego, lecz ma on w dużym stopniu charakter poglądowy w przypadku analizy antropopresji w zlewniach rzecznych.

Sposób obliczeń wskaźnika antropopresji oparty na danych przestrzennych wydaje się bardziej wiarygodny w odniesieniu do obszarów systemów przyrodniczych. Zarówno mapa pokrycia terenu CORINE Land Cover, jak i Mapa Hydrograficzna Polski prezentują przestrzenne rozmieszczenie użytków i obszarów zdrenowanych, które analizować można bezpośrednio w granicach zlewni. Eliminuje to potrzebę uogólniania stosowanego w przypad$\mathrm{ku}$ danych statystycznych. $\mathrm{Z}$ drugiej strony ze względu na skalę opracowania danych na mapie pokrycia terenu (minimalny obszar kartowania to $25 \mathrm{ha}$ ) oraz mapie hydrograficznej (skala 1:50 000) zachodzi generalizacja form użytkowania terenu i obszarów zdrenowanych. Przykładem generalizacji wynikającej ze skali opracowania na mapie pokrycia terenu jest niemal znikomy udział sadów w ogólnej powierzchni Gór Świętokrzyskich (poniżej $0,02 \%$ ). Ponadto brak również powyższej kategorii użytków na terenie zlewni Kamiennej, Koprzywianki i Czarnej, podczas gdy w każdej z gmin wchodzących w ich skład według danych statystycznych GUS sady występują. 


\section{Wnioski}

Wysoka wartość wskaźnika antropopresji, który opracował Soja (2002), zależna jest od przeważającego udziału gruntów ornych, obszarów zdrenowanych i pozostałych gruntów w stosunku do użytków zielonych, lasów, sadów i/lub od znacznej gęstości zaludnienia. Na przykładzie zlewni 2. rzędu w Górach Świętokrzyskich dowiedziono, że zróżnicowanie wartości wskaźnika antropopresji w poszczególnych zlewniach wynika głównie z różnic gęstości zaludnienia oraz udziału $w$ tych zlewniach gruntów ornych, lasów i pozostałych gruntów, w tym zwłaszcza obszarów zabudowy. Udział pozostałych kategorii użytkowania terenu (łąki i pastwiska, sady) oraz powierzchni zdrenowanych jest natomiast $\mathrm{w}$ analizowanych zlewniach porównywalny i nie ma większego wpływu na zróżnicowanie wartości wskaźnika.

Zlewnie 2. rzędu w Górach Świętokrzyskich charakteryzują się przewagą obszarów wpływających negatywnie na obieg wody, w tym zwłaszcza gruntów ornych w stosunku do obszarów roślinności trwałej - sadów oraz łąk i pastwisk. Decyduje to o wzmożonej presji antropogenicznej w zlewniach rzecznych i rodzi potrzebę jej oceny ilościowej. W badanych zlewniach dowiedziono zróżnicowania warunków antropopresji. Na tle zlewni mezoregionu wyraźnie wyróżnia się zlewnia Koprzywianki o najwyższej wartości wskaźnika antropopresji, która tym samym jest $\mathrm{w}$ największym stopniu zagrożona zmianami obiegu wody wynikającymi z działalności człowieka. W pozostałych zlewniach zaobserwowano porównywalne nasilenie antropopresji.

Odnotowano zróżnicowanie wartości wskaźnika antropopresji w zależności od ukształtowania terenu oraz odległości od miast. Rzeźba powierzchni stwarza warunki do rozwoju określonych form użytkowania gruntów, przez co oddziałuje na zróżnicowanie warunków antropopresji w zlewniach mezoregionu. Przy dużych spadkach terenu i znacznych wysokościach bezwzględnych wartości wskaźnika antropopresji są niższe, co w Górach Świętokrzyskich znajduje potwierdzenie w przewadze na takich terenach lasów nad formami presji antropogenicznej. Obszary o niewielkich spadkach i nieznacznych wysokościach bezwzględnych charakteryzują się natomiast zwiększonym udziałem pozostałych form użytkowania terenu, w tym gruntów ornych i terenów zabudowy, a wartości wskaźnika antropopresji są wówczas bardziej zróżnicowane. W pracy dostrzeżono również wyraźne dysproporcje w wartości wskaźnika antropopresji między obszarami miast a terenami do nich przyległymi. Wynika to głównie z różnic gęstości zaludnienia oraz udziału terenów zabudowy miejskiej w powierzchni. Na obszarach miejskich o zwartej zabudowie wartości wskaźnika antropopresji przewyższają nawet kilkakrotnie te osiągane na obszarach oddalonych od miast. W poszczególnych strefach odległości od miast warunki antropopresji są jednakże przede wszystkim wynikiem rozmieszczenia form użytkowania terenu, które nie ma ścisłego związku $\mathrm{z}$ odległością od miast.
Zastosowane w pracy dwa sposoby obliczania wartości wskaźnika antropopresji mają ograniczenia, wynikające z niezgodności granic jednostek podziału administracyjnego i zlewni rzecznych (1. sposób - dane statystyczne) bądź generalizacji będącej konsekwencją skali opracowania (2. sposób - dane przestrzenne). Do obliczania wartości wskaźnika antropopresji, szczególnie na niewielkich obszarach takich, jak Góry Świętokrzyskie, bardziej zasadne wydaje się wykorzystywanie danych przestrzennych, które umożliwiają analizę antropopresji bezpośrednio $\mathrm{w}$ granicach zlewni, bez konieczności stosowania uogólnień. Coraz większa dostępność danych $\mathrm{w}$ formie numerycznej sprzyja analizom przeprowadzanym niezależnie od granic jednostek administracyjnych.

Wykorzystany w pracy wskaźnik antropopresji umożliwia przeprowadzenie analizy porównawczej nasilenia antropopresji na danym obszarze. Jednocześnie, uwzględniając jedynie wybrane czynniki presji antropogenicznej, stanowi on niepełną miarę oceny oddziaływania człowieka na obieg wody. W celu uzyskania kompleksowej oceny warunków antropopresji i ich wpływu na obieg wody niezbędne jest wzbogacenie powyższego wskaźnika w dodatkowe elementy - czynniki antropopresji. Istotne jest między innymi uwzględnienie zabudowy koryt, ujęć wody, punktów zrzutu ścieków czy zbiorników retencyjnych. Wykracza to jednakże poza zakres niniejszej pracy.

Kwestią problemową w obliczaniu wartości wskaźnika antropopresji jest też sposób ustalania przedziałów gęstości zaludnienia, jak również przypisywania im wartości współczynnika gęstości zaludnienia (K). W opracowaniu wzorowano się ściśle na metodzie, którą opracował Soja (2002). Kwestią sporną jest jednakże stwierdzenie, czy zastosowany przedział wartości współczynnika K (od $-0,4$ do $+0,4$ ) uwzględnia w odpowiednim stopniu wpływ gęstości zaludnienia na kształtowanie się warunków antropopresji. Przykład Kielc pokazuje, że w metodyce obliczania powyższego wskaźnika zbyt duże znaczenie przypisywane jest formom użytkowania terenu w przeciwieństwie do gęstości zaludnienia. Ranga tego miasta wojewódzkiego o gęstości zaludnienia wynoszącej aktualnie około 1823 os. $\mathrm{km}^{-2}$ została przy obliczaniu wskaźnika niemal zupełnie zatarta. Wartość wskaźnika antropopresji w przypadku Kielc wynosi bowiem 2,83 i jest porównywalna $\mathrm{z}$ wartościami dla gmin rolniczych, m.in. takich jak Baćkowice i Klimontów o udziale gruntów ornych powyżej $60 \%$. Jest to ponadto wartość stosunkowo niska w porównaniu do maksymalnej wartości tego wskaźnika w Górach Świętokrzyskich $(7,81)$, która występuje w znacznie wylesionej gminie Opatów.

\section{Podziękowania}

Dziękuję prof. Tadeuszowi Ciupie za okazaną pomoc przy realizacji powyższego tematu. 


\section{Literatura}

Absalon D., 1998. Antropogeniczne zmiany odpływu rzecznego w zlewni Rudy. UŚ, Katowice.

CGIAR-CSI, 2004. SRTM $90 \mathrm{~m}$ Digital Elevation Data. Online 20.05.2013 - http://srtm.csi.cgiar.org.

Ciupa T., 2009. Wpływ zagospodarowania terenu na odpływ i transport fluwialny w małych zlewniach na przykładzie Sufragańca i Silnicy (Kielce). UJK, Kielce.

Ciupa T., 2010. Zastosowanie wskaźnika stabilności obszarowej zlewni do analizy wybranych cech odpływu i transportu fluwialnego na przykładzie Sufragańca i Silnicy. Landform Analysis 13: 5-11.

Czaja S., 1988. Wpływ górnictwa i uprzemysłowienia na reżim odpływu rzek w Górnośląskim Okręgu Przemysłowym na przykładzie zlewni Brynicy do profilu w Sosnowcu. W: I. Dynowska (red.), Antropogeniczne uwarunkowania zmian odpływu i reżimu rzek w różnych regionach Polski. Dokumentacja Geograficzna IGiPZ PAN, 4: 65-77.

Czaja S., 1999. Zmiany stosunków wodnych w warunkach silnej antropopresji (na przykładzie konurbacji katowickiej). Prace Naukowe UŚ 1782: 189 .

Czaja S., 2002. Zmiany struktury i reżimu odpływu rzecznego na obszarach górniczo-przemysłowo-miejskich W: T. Ciupa i in. (red.), Obieg wody w zmieniającym się środowisku. Prace Instytutu Geografii AŚ 7: $65-76$.

Dynowska I. (red.), 1993. Przemiany stosunków wodnych w Polsce w wyniku procesów naturalnych i antropogenicznych. UJ, Kraków.

EEA, 2013. CORINE Land Cover. Online 15.05.2013 - http://www.eea. europa.eu.

Giełda-Pinas K., 2012. Waloryzacja przyrodnicza krajobrazu Pojezierza Gnieźnieńskiego. Problemy Ekologii Krajobrazu 33: 77-85.

GIOŚ, 2008. Klasyfikacja form pokrycia terenu CLC. Online 23.05.2013 - http://clc.gios.gov.pl.

Jankowski A.T., 1986. Antropogeniczne zmiany stosunków wodnych na obszarze uprzemysłowionym i urbanizowanym (na przykładzie Rybnickiego Okręgu Węglowego). Prace Naukowe UŚ.
Jankowski A.T., 1998. Antropogeniczne uwarunkowania obiegu wody na terenie Górnośląskiego Zagłębia Węglowego. W: A. Magnuszewski, U. Soczyńska (red.), Hydrologia u progu XXI wieku. Komisja Hydrologiczna PTG, Warszawa: 139-156.

Kostrowicki A.S., 1992. System człowiek-środowisko w świetle teorii ocen. Prace Geograficzne IGiPZ PAN.

Maruszczak H., 1986. Tendencje sekularne i zjawiska ekstremalne w rozwoju rzeźby małopolskich wyżyn lessowych w czasach historycznych. Czasopismo Geograficzne 57, 2: 271-282.

Michalczyk Z. (red.), 2012. Ocena warunków występowania wody i tworzenia się spływu powierzchniowego w Lublinie. Badania hydrograficzne w poznawaniu środowiska, X. Wyd. UMCS, Lublin.

Michalczyk Z., Łoś M.J., 1996. Przemiany stosunków wodnych w okolicy Lublina. W: A.T. Jankowski, A. Kaniecki (red.), Dziejowe przemiany stosunków wodnych na obszarach zurbanizowanych. Wyd. UAM, Poznań: 96-107.

Nowicka B., 2002. Wpływ urbanizacji na warunki odpływu. Prace Instytutu Geografii AŚ 7: 77-86.

Piotrowska I., 2001. Wykorzystanie modelu erozji wodnej gleb w badaniach użytkowania ziemi i opracowaniach scenariuszy rozwoju erozji gleb na obszarze młodoglacjalnym (zlewnia górnej Parsęty, Pomorze Zachodnie). W: A. Karczewski, Z. Zwoliński (red.), Funkcjonowanie geoekosystemów w zróżnicowanych warunkach morfoklimatycznych. Monitoring, Ochrona, Edukacja. Bogucki Wydawnictwo Naukowe, Poznań: 425-438.

Plit J., 1996. Antropogeniczne i naturalne przeobrażenia krajobrazów roślinnych Mazowsza (od schyłku XVIII w. do 1900 r.). Prace Geograficzne IGiPZ PAN 166: 1-135

Soczyńska U., 1974. Hydrologiczne skutki urbanizacji. Wiadomości Meteorologii i Gospodarki Wodnej 22(4): 11-22.

Soja R., 2002. Hydrologiczne aspekty antropopresji w polskich Karpatach. Prace Geograficzne IGiPZ PAN 186: 1-130.

Wilgat T., 1978. Zmiany struktury obiegu wody pod wpływem działalności gospodarczej. W: Antropogeniczne zmiany stosunków wodnych. Komisja Hydrograficzna PTG, UMCS, Lublin: 7-20. 